\title{
To What Extent is Leader-member Exchange and Psychological Safety Able to Influence Counterproductive Work Behavior? Evidence from the Hospitality Industry in Surabaya, Indonesia
}

\author{
Adrie Oktavio* \\ Department of Hospitality Business, Faculty of Tourism, Universitas Ciputra Surabaya, \\ Citraland CBD Boulevard, Made, Surabaya 60219, Indonesia
}

\begin{abstract}
Counterproductive work behavior (CWB) is a form of behavioral and unethical deviation that can threaten the existence of companies including the hotel industries that uphold the values of hospitality in their services. This study analyzes how CWB can be anticipated or minimized its appearance through the improvement of leader-member exchange (LMX) and psychological safety quality relationships as its mediation. The results of the study using the SmartPLS analysis tool on 124 hotel employees showed that LMX directly had a negative influence on CWB. On the other hand, LMX had a positive effect on psychological safety. However, psychological safety did not have an influence on CWB, so psychological safety is also unable to act as mediation in this research model.
\end{abstract}

Keywords: Employee, hotel, leader-member exchange, psychological safety, unethical deviation.

\section{Introduction}

The availability of competent employees is one factor that is very crucial for the survival of a company, including hotels [1]. Competition between companies to obtain the best human resources becomes fierce, especially human resources that have good work ethics [2]. Good employee work ethics is one of them in terms of employee behavior in work that prioritizes productivity [3]. Conversely, work attitudes that are contrary to the spirit of productivity are often referred to as counterproductive work behavior (CWB) [4].

CWB is a description of someone's behavior that is intentional and can endanger other individuals and organizations. CWB can occur on a small level or scales, such as extending breaks during lunch, or even on a larger level or scale, such as acts of violence against coworkers. Penney \& Spector and Cohen, et al. add that CWB, which involves harassment of others, deviations in productivity, sabotage, and theft, is very unethical and a threat to the welfare of the organization and its members $[5,6]$.

\footnotetext{
* Corresponding author: adrie.oktavio@ ciputra.ac.id
} 
Some studies have found that the emergence of CWB is often motivated by an attitude of disobedience in the workplace resulting in violent behavior, vandalism, sabotage and so on [7]. Meanwhile, Gruys \& Sackett managed to identify several categories of CWB, including property destruction, misuse of information, misuse of time and resources, low absenteeism, poor quality work, alcohol and drug consumption, and inappropriate verbal behavior [8]. Gruys \& Sackett also found a negative correlation between CWB and age and work experience [8]. This is in line with the findings of Barling, Dupré, \& Kelloway, which show that as a person ages, the tendency towards an act of violence also decreases. With increasing age, emotional control is getting better because the level of awareness of the consequences of actions and behavior that is done is also getting higher [9].

In the working world or organizations, including hotels, counterproductive work behavior (CWB) has often happened and is not a new phenomenon [10, 11]. As a consequence, CWB can cause a company's reputation to be bad so it will require considerable costs to restore that reputation [12]. Therefore, a strong understanding of the factors that affect CWB is needed to be minimized or prevented so that it does not cause greater losses to the company [13, 14].

One important factor that can influence CWB is the quality of the relationship between superiors and subordinates or commonly known as the Leader-Member Exchange (LMX). Subordinates who have poor quality relationships with their leaders often experience stress, feel harassed and get discriminatory treatment [15]. In theory, LMX considers leadership as part of an employee development process that is massive in a relationship between superiors and subordinates $[16,17]$. On the other hand, most managers are more likely to develop a working relationship that is closer to some employees due to limited time and energy [18]. Therefore, the LMX theory places more emphasis on the aspects of reciprocal relations between superiors and employees [19]. Relationships between superiors and subordinates are also dynamic, which always develops from time to time through a series of exchanges between them [20]. LMX consists of high-quality relationships and low relationship quality [21]. High-quality LMX is called in-group, and low-quality LMX is called out-group [22]. Although these exchanges are differentiated into high-quality, lowquality exchanges, this theory assumes that the level of connectivity develops over time. For example, superiors and subordinates who have different experience backgrounds require them to learn from each other, so that their relationships will also develop [20]. In its development, the quality of relations between superiors and subordinates is also influenced by situational factors, individual factors, organization factors, and psychological processes [23].

Dadhich \& Bhal further defines LMX as a reciprocal relationship between superiors and subordinates, which focuses on building trust [19]. The main premise built into this theory is that employers tend to differentiate subordinates so that the treatment of superiors to subordinates also varies [24]. Relationships that are intertwined in LMX are characterized by the level of trust in the implementation of tasks that require responsibility, decision making, emotional support, increased security, and an increase in employee interest in work [25]. Employees who feel trusted by their leaders often feel safe to do the work assigned to them, discuss mistakes and at the same time, share knowledge [26, 27]. Thus, a positive relationship between superiors and subordinates will further increase the likelihood of employees becoming more loyal to the organization, and on the other hand can also reduce the possibility of negative behavior [28, 29].

On the other hand, the relationship between superiors and subordinates, especially those felt by employees, greatly influences employee perceptions in terms of psychological safety. Bosses being able to create a conducive work environment so that it is possible to share knowledge indirectly, can influence the level of psychological safety of employees [30]. Conversely, if the work environment is always colored by uncertainty in the work, 
then the potential for the emergence of greater work stress will have an impact on the emotion and behavior of individuals [31, 32], and job satisfaction that leads to low efficiency in working and generating CWB in the workplace [27]. Psychological safety is defined as the ability of individuals to show their identity without feeling afraid of the emergence of negative consequences related to self-image, status, and career [33], so that they are free to express themselves. Edmondson in his research, found that building selfconfidence is an important factor in creating psychological safety [26]. Especially in a team, psychological safety can surpass the confidence of each team member. Psychological safety refers to safety in terms of maintaining work relationships in the workplace and open communication. On the other hand, uncertainty in work can potentially lead to feelings of stress that can affect the emotions and behavior of individuals and ultimately can affect the physical and psychological resilience of individuals who can interfere with work efficiency [27]. Edmondson, et al. added that psychological safety is a situation where there is a guarantee of safety in taking risks in the workplace so that employees dare to speak openly, for example, developing and implementing new ideas [34]. It is undeniable that sometimes these new ideas have a high risk [35], and the potential for failure is also quite large [36], so that they get rejected because they are considered behaviors deviate. However, regardless of the success or failure of new ideas voiced by employees, a psychologically safe work environment is still needed by employees to dare to voice these new ideas and at the same time, dare to take risks [26].

\section{Problem Statement}

Profit-oriented companies must be able to control the different characteristics and behaviors of their employees in order to survive or gain a sustainable competitive advantage [37]. It means that absolutely managerial parties need to understand thoroughly about the problems that affect employee-oriented work outcomes [38]. Managerial parties are demanded to be able to identify factors that affect performance, productivity, and the level of efficiency of employees [39].

The diverse nature and behavior of employees enable the emergence of negative behaviors that have an impact on organizational performance [40], one of which is CWB [41]. According to Uchenna, in certain conditions, most employees have the intention to do some form of CWB [42]. The appearance of CWB can be impulsive and describe the attributes of antisocial behavior [43]. CWB, as a form of employee behavior deviation in work has a variety that is very varied and done intentionally. Therefore, CWB has been considered a severe problem because it can have a very detrimental impact on the company and also requires a small amount of money to overcome it. Lasisi et al., add that CWB is like a hurricane, which, if left unchecked, would become increasingly uncontrollable and has a great opportunity to erode the competency of the company and ultimately push the company to the brink of collapse [38]. Thus, anticipatory measures and efforts to improve the impact of CWB need to get more serious attention. As early as possible managerial parties must be able to limit the opportunities for CWB to emerge in the work environment [5]. A thorough understanding of the employee's personality is one important step towards understanding and at the same time, a better approach to improving the impact of CWB in the workplace [44].

The CWB construct is often discussed in many previous studies, and almost all agree that CWB is an crucial aspect related to organizational performance. Until now, most of CWB's research has highlighted many aspects of the relationship between work attitudes (e.g., job satisfaction), environmental factors (eg conscience, locus of control, and psychological safety), and leadership (for example, leadership style, boss relations with subordinates) $[5,11,12,27,37,42,45]$. However, previous studies that tried to combine 
aspects of leadership and personality traits as aspects that should be prioritized in an effort to anticipate the emergence of CWB have never been done especially in the context of employment in the field of hospitality in Indonesia.

\section{Research Question}

The extent to which LMX can influence CWB both directly and through psychological safety as an intervening variable is a question analyzed in this study.

\section{Purpose of the Study}

This research aims to contribute to the understanding of CWB. To find these objectives, the researchers attempted to analyze and provide solutions to some of the main problems in the work environment to reduce CWB. Therefore, researchers try to describe the impact of LMX quality and psychological safety on CWB in the hotel sector, considering that employees who work in that sector have high job demands both in terms of expertise and emotionality, so that it directly or indirectly influences the emergence of CWB.

\section{Conceptual Model}

\subsection{Relationship between LMX to CWB}

Liu et al., illustrate that in a company, an ideal leader ideally has full control over the behavior of employees [29]. Thus, negative behavior or CWB from employees should be able to be controlled and anticipated by improving the quality of relations between superiors and subordinates. Positive relationships between superiors and subordinates will further increase the likelihood of employees becoming increasingly loyal to the organization, and on the other hand, it can also reduce the possibility of negative behavior $[28,29]$. Dular \& Markič add that the emergence of undesirable negative behaviors in organizations is influenced by the presence of leaders as forming organizational values and norms as well as controlling resources within the organization [46]. Chernyak-Hai \& Tziner also assume that if there is a high social exchange between superiors and subordinates, as an important element in relationship development, it can reduce negative experience in the organization [47]. Thus, the perception of the quality of LMX felt by each individual in the organization has different levels so that the potential for the emergence of CWB from each individual is also different [48].

\section{$\mathrm{H}_{1}$ : LMX has a negative effect on CWB}

\subsection{The relationship between LMX on psychological safety}

A high LMX relationship is influenced by several factors, such as job challenges, decision making, and emotional support [25]. Relationships between superiors and subordinates characterized by these factors must improve the perception of work security or comfort [26], self-determination \& interest of employees in their work [32]. Employees need to feel psychologically safe so that they can optimally do the work assigned to them, discuss errors that arise in work and at the same time, share knowledge [26, 27]. Conversely, employees who feel psychologically insecure will tend to think of their leaders as supervisors who always monitor employees' movements [49]. These explanations ultimately lead to the assumption that the quality of a high LMX relationship will help employees feel safe in their work team, while if the quality of LMX relationships is low, it can be a barrier to the realization of psychological safety feelings. 
$\mathrm{H}_{2}$ : LMX has a positive effect on Psychological Safety

\subsection{The relationship between psychological safety on CWB}

A conducive work environment makes it possible for individuals to share the knowledge that has an impact on increasing psychological safety. Psychological safety is defined as an employee's ability to show identity without feeling afraid of the emergence of negative consequences related to self-image, status, and career [33]. When employees feel safe, the employee can understand the limits of acceptable behavior. It is different when the work situation is unpredictable, full of ambiguity and can even threaten the employee [32], the employee will feel depressed, experience emotional disturbances and can ultimately affect the physical and psychological resilience of the individual that can interfere with work efficiency if left unchecked it will potentially lead to CWB in employees [27].

H3: Psychological Safety has a negative effect on CWB

\subsection{Psychological safety as a mediator between LMX and CWB}

LMX will have a smaller role if the work environment is in uncomfortable conditions. While on the one hand, LMX also functions as social support for members of the company. When employees feel uncomfortable at work, they tend to rely on good relationships with leaders to minimize the inconvenience. Conversely, if the inconvenience worsens and the relation between the boss and subordinate is also not harmonious, then the two combinations can increase the chances of creating negative behavior from employees [50]. H4: Psychological Safety mediates the effect of LMX on CWB

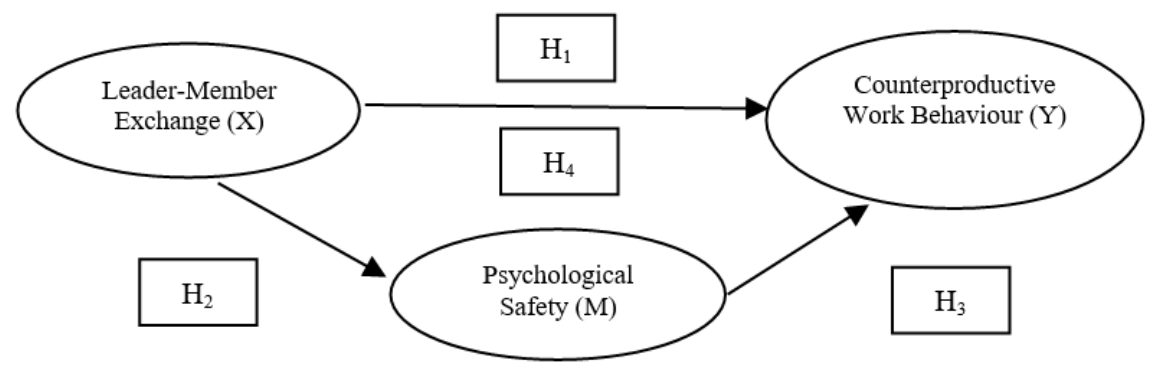

Fig. 1. Research model

\section{Research method}

The sample used in this study was star-rated hotel employees in the city of Surabaya. Purposive sampling was chosen by the researcher as a sampling technique where sampling was carried out proportionally and based on two main considerations, namely the willingness of the hotel to be sampled and the wide area of the hotel distribution area in Surabaya. The research sample was taken in June to July 2019. The questionnaire was given to permanent hotel employees who have been working for at least two years spread over 30-star hotels covering fifteen 3-star hotels, ten 4-star hotels, and five 5-star hotels.

Each hotel receives five questionnaires so that the total number of questionnaires distributed is 150 questionnaires. The selection of employees who are trusted to fill out the questionnaire is the authority of the respective hotel management. From the results of the 
questionnaire dissemination, the researchers managed to get 124 questionnaires $(82.7 \%)$ that returned and were eligible for data processing. The data analysis method uses SEM (Structural Equation Modeling) based on Partial Least Square.

The overall indicators used to measure the variables of this study adopt from several previous studies. 11 LMX measuring indicators are adapted from the research of Kuvaas, Buch, Dysvik, \& Haerem and Graen \& Uhl-Bien [49, 51]. The Psychological Safety variable is measured by seven indicators from Edmondson's study [26]. While the CWB variable uses 18 indicators belonging to the research of Spector et al. [52].

\section{Findings}

Based on the results of the questionnaire data, it is found that 57 respondents (46\%) are men, while the remaining 67 respondents $(54 \%)$ are women. From the age factor, 71 respondents $(57 \%)$ are employees of the age group of $20 \mathrm{yr}$ to $30 \mathrm{yr}$; 42 respondents (34\%) are $31 \mathrm{yr}$ old to $40 \mathrm{yr}$ old, and the remaining 11 respondents $(9 \%)$ are over $40 \mathrm{yr}$ old. Furthermore, from the employee working period, it is known that 79 respondents $(64$ $\%$ ) have been working for $2 \mathrm{yr}$ to $4 \mathrm{yr} ; 34$ respondents (27\%) have been working in the range of $5 \mathrm{yr}$ to $10 \mathrm{yr}$, and 11 respondents $(9 \%)$ have been working for more than ten years at the hotel. From the marital status, the data says that 65 respondents $(52 \%)$ were married; and the remaining 59 respondents (48\%) were not married.

The next step is to evaluate the outer model (measurement model) through convergent validity, discriminant validity, and composite reliability. The results of the convergent validity test in Table 1 show that the overall indicator meets the requirements because the outer loading value is above 0.5 .

Table 1. Outer loading

\begin{tabular}{|c|c|c|c|c|c|}
\hline Item & $\begin{array}{c}\text { Loading } \\
\text { Factor }\end{array}$ & Validity & Item & $\begin{array}{c}\text { Loading } \\
\text { Factor }\end{array}$ & Validity \\
\hline $\mathrm{X}_{1}$ & 0.753 & Valid & $\mathrm{Y}_{1}$ & 0.916 & Valid \\
\hline $\mathrm{X}_{2}$ & 0.867 & Valid & $\mathrm{Y}_{2}$ & 0.916 & Valid \\
\hline $\mathrm{X}_{3}$ & 0.729 & Valid & $\mathrm{Y}_{3}$ & 0.948 & Valid \\
\hline $\mathrm{X}_{4}$ & 0.867 & Valid & $\mathrm{Y}_{4}$ & 0.755 & Valid \\
\hline $\mathrm{X}_{5}$ & 0.821 & Valid & $\mathrm{Y}_{5}$ & 0.928 & Valid \\
\hline $\mathrm{X}_{6}$ & 0.833 & Valid & $\mathrm{Y}_{6}$ & 0.722 & Valid \\
\hline $\mathrm{X}_{7}$ & 0.854 & Valid & $\mathrm{Y}_{7}$ & 0.714 & Valid \\
\hline $\mathrm{X}_{8}$ & 0.822 & Valid & $\mathrm{Y}_{8}$ & 0.722 & Valid \\
\hline $\mathrm{X}_{9}$ & 0.765 & Valid & $\mathrm{Y}_{9}$ & 0.745 & Valid \\
\hline $\mathrm{X}_{10}$ & 0.872 & Valid & $\mathrm{Y}_{10}$ & 0.816 & Valid \\
\hline $\mathrm{X}_{11}$ & 0.843 & Valid & $\mathrm{Y}_{11}$ & 0.826 & Valid \\
\hline $\mathrm{M}_{1}$ & 0.818 & Valid & $\mathrm{Y}_{12}$ & 0.879 & Valid \\
\hline $\mathrm{Item}_{2}$ & $\begin{array}{c}\text { Loading } \\
\text { Factor }\end{array}$ & Validity & $\mathrm{Item}$ & $\begin{array}{c}\text { Loading } \\
\text { Factor }\end{array}$ & Validity \\
\hline $\mathrm{M}_{2}$ & 0.765 & Valid & $\mathrm{Y}_{13}$ & 0.819 & Valid \\
\hline $\mathrm{M}_{3}$ & 0.851 & Valid & $\mathrm{Y}_{14}$ & 0.808 & Valid \\
\hline $\mathrm{M}_{4}$ & 0.731 & Valid & $\mathrm{Y}_{15}$ & 0.841 & Valid \\
\hline $\mathrm{M}_{5}$ & 0.794 & Valid & $\mathrm{Y}_{16}$ & 0.823 & Valid \\
\hline $\mathrm{M}_{6}$ & 0.768 & Valid & $\mathrm{Y}_{17}$ & 0.729 & Valid \\
\hline $\mathrm{M}_{7}$ & 0.820 & Valid & $\mathrm{Y}_{18}$ & 0.714 & Valid \\
\hline
\end{tabular}

Source: Output Result of SmartPLS.

In addition to convergent validity, the validity of indicators is also seen from the discriminant validity test by comparing the correlation values of latent variables with AVE 
root values (see Table 2 and Table 3). The root value of AVE for LMX construct is 0.817 , while the correlation value between LMX and other constructs is 0.779 . Thus, discriminant validity is considered to have fulfilled the requirements because the AVE root value is higher compared to the correlation value with other constructs. The same is the case with the AVE root values of the Psychological Safety and CWB constructs that produce higher values.

Table 2. The correlation of latent variabel

\begin{tabular}{|c|c|c|c|}
\hline & LMX & $\begin{array}{c}\text { Psychological } \\
\text { Safety }\end{array}$ & CWB \\
\hline LMX & 1 & & \\
\hline Psychological Safety & 0.779 & 1 & \\
\hline CWB & -0.640 & -0.659 & 1 \\
\hline
\end{tabular}

Source: Output Result of SmartPLS

Table 3. Root of AVE

\begin{tabular}{|c|c|c|}
\hline Variabel & AVE & Root of AVE \\
\hline LMX & 0.667 & 0.817 \\
\hline Psychological Safety & 0.636 & 0.797 \\
\hline CWB & 0.866 & 0.930 \\
\hline
\end{tabular}

Source: Output Result of SmartPLS

After it is known that the overall indicators in this study meet the element of validity, the indicators must also be tested for reliability (see Table 4). If the composite reliability and Cronbach's alpha values are above 0.7 , it is said to be reliable.

Table 4. Reliability test

\begin{tabular}{|c|c|c|}
\hline Variable & $\begin{array}{c}\text { Composite } \\
\text { Reliability }\end{array}$ & $\begin{array}{c}\text { Cronbach's } \\
\text { Alpha }\end{array}$ \\
\hline LMX & 0.956 & 0.950 \\
\hline Psychological Safety & 0.958 & 0.952 \\
\hline CWB & 0.951 & 0.922 \\
\hline
\end{tabular}

Source: Output Result of SmartPLS

In addition to evaluating the outer model (measurement model), the results of PLS data processing also evaluated the inner model (structural model) described through the results of R-Square values (test goodness-fit model), Q-Square (predictive relevance) and hypothesis testing. In Table 5, the R-Square value for the CWB construct is 0.650 , which means that CWB can be explained by LMX variables and psychological safety by $65 \%$, while the remaining $35 \%$ is explained by other variables outside the model. The psychological safety construct has a R-Square value of 0.475 which means that psychological safety can be explained by LMX variables of $47.5 \%$ and the remaining $52.5 \%$ is explained by other factors outside the model studied.

Table 5. R-Square result

\begin{tabular}{|l|c|}
\hline \multicolumn{1}{|c|}{ Variabel } & R-Square \\
\hline CWB & 0.650 \\
\hline Psychological Safety & 0.475 \\
\hline
\end{tabular}

Source: Output Result of SmartPLS 
After the R-Square value is known, then the Q-Square test is performed which serves to validate the model's predictive ability.

$$
\begin{aligned}
& \mathrm{Q} 2=1-\left(1-\mathrm{R}^{2}\right)\left(1-\mathrm{R}^{2}\right) \\
& \mathrm{Q} 2=1-(1-0,650)(1-0.475) \\
& \mathrm{Q} 2=1-(0.350)(0.525) \\
& \mathrm{Q} 2=1-0.183 \\
& \mathrm{Q} 2=0.817
\end{aligned}
$$

Based on the results of the Q-Square calculation above, it shows that the magnitude of the diversity of the research data that can be explained by the structural model is $81.7 \%$, while the remaining $18.3 \%$ is explained by other factors that are outside the research model.

To get answers to the research hypothesis, in Table 6, the results of hypothesis testing are presented which contain the path coefficients and t-statistics.

Table 6. Path coefficients and t-values

\begin{tabular}{|l|c|c|c|}
\hline \multicolumn{1}{|c|}{ Hypotheses } & $\begin{array}{c}\text { Path } \\
\text { Coefficients }\end{array}$ & $\begin{array}{c}\text { t- } \\
\text { statistic }\end{array}$ & Status \\
\hline $\mathrm{H}_{1}:$ LMX $\rightarrow$ CWB & -0.384 & -2.909 & Accepted \\
\hline $\mathrm{H}_{2}:$ LMX $\rightarrow$ Psychological Safety & 0.505 & 4.854 & Accepted \\
\hline $\mathrm{H}_{3}:$ Pscyhological Safety $\rightarrow$ CWB & -0.045 & -0.426 & Rejected \\
\hline
\end{tabular}

Source: Output Result of SmartPLS

From the results of hypothesis testing in Table 6, it is known that only the first and second hypotheses are acceptable because the t-statistic value is above 1.96. The results of the first hypothesis test show a negative effect between LMX on CWB with significance at alpha $5 \%$ as indicated by the value of t statistic $-2.909<-1.96$. The results of the second hypothesis test concerning the effect of LMX on psychological safety are significant with a t-statistical value of $4.854>1.96$. The value of path coefficients is positive which is equal to 0.505 which indicates that the direction of the relationship between LMX to psychological safety is positive. While the third hypothesis test related to the influence of psychological safety on CWB shows a negative effect but not significant because the $\mathrm{t}$ statistic value is $-0.426>-1.96$, so the third hypothesis is rejected.

To answer the fourth hypothesis related to the role of psychological safety as an intervening variable that mediates the effect of LMX on CWB, this study refers to the results of research by Baron \& Kenny which states that the main requirement for mediation testing is the significant influence of independent variables on intervening variables [53], and there is also a significant influence from the intervening variable to the dependent variable. If one of these conditions is not met, then no mediation test is needed. Thus, the fourth hypothesis proposed in this study is declared rejected because psychological safety as an intervening variable does not significantly influence the CWB variable as an independent variable.

\section{Discussion}

\subsection{LMX has a negative effect on CWB}

The results show that the first hypothesis is acceptable where there is a significant influence between LMX and CWB and shows the direction of a negative relationship. This is in line with research [28, 29, 47]. The higher the LMX level that occurs in a work environment will further minimize the potential for CWB to be initiated by employees. Huang et al., and Liu et al., said that a positive relationship between superiors and subordinates will further increase the likelihood of employees becoming increasingly loyal to the organization, and 
on the other hand it can also reduce the possibility of negative behavior [28, 29]. For employees who have relationships with leaders based on mutual trust and recognition of their potential, there is little chance of carrying out unwanted behavior in the workplace. According to social exchange theory, an employee who reacts (actions and responses) positively to the company will encourage these employees to become more committed and potentially reduce negative behavior such as CWB [54].

\subsection{LMX has a positive effect on psychological safety}

Proof of the second hypothesis of this study shows a positive and significant influence between LMX and psychological safety. The results of this study support Furtado and Van den Broeck et al., [27, 55]. Furtado in his research concluded that quality LMX would make the psychological safety of each individual in an organization also higher [55]. The good quality of LMX is able to stimulate employee perceptions that the work environment in which he works today is very comfortable, there is open communication and discuss errors that arise in work and at the same time share knowledge [27]. Conversely, the role of LMX is lower in terms of discomfort in work because it does not function as social support for each individual in the organization [50]. For example, leaders do not create a work environment where employees are given less space to voice new ideas regarding the work they are doing. Such leaders usually often do not have the attributes of openness to employees so that it does not encourage employees to act innovatively. Supposedly, leaders need to provide assurance to employees to keep conveying innovative thoughts without negative consequences for employees in the form of sanctions so that the psychological safety of employees will increase [56]. When employees experience good psychological safety, they tend to be more open to express themselves without fear of negative consequences $[26,34]$.

\subsection{Psychological safety does not affect CWB so psychological safety is not a mediator between LMX and CWB}

The conceptual model in Figure 1 which predicts the influence of psychological safety on CWB (third hypothesis) cannot be proven in this study. Therefore, the fourth hypothesis which assumes that psychological safety as a mediator of LMX relations to CWB also falls because psychological safety as an intervening variable does not affect CWB as a dependent variable [53]. In a study, Carmeli et al. stated that CWB is more dependent on the quality of interpersonal relationships within the organization. Thus, the quality of employee relations with their leaders more plays a more important role in predicting the application of counterproductive behavior as individual factors [57]. Superiors who are able to show their closeness to employees will influence the personality of employees in perceiving the work environment positively so as to distance them from the tendency of CWB [58]. This means that employees with a higher level of emotional intelligence will react to perceived injustices before, which can lead to undesirable behavior [59].

\section{Conclusions}

In this study, we tested the effect of LMX, psychological safety and its effect on CWB. The results show that LMX affects CWB. LMX also affects psychological safety. Conversely, psychological safety does not affect CWB so psychological safety cannot act as a mediator between LMX and CWB. From the overall findings of this study, it can be concluded that 
star-rated hotel employees, as the object of this study, assume that situational factors such as LMX play a more important role than individual factors such as psychological safety.

\subsection{Future research}

The CWB construct has been quite widely discussed in western literature, such as Europe and America. Some researchers in Indonesia have also carried out studies on counterproductive behavior. However, studies conducted in Indonesia (including this study) still adopt CWB measurement indicators from western studies without trying to analyze CWB indicators based on Indonesian culture itself so that there is a possibility of differences in measurement due to these cultural differences.

\section{References}

1. R. Cheraghalizadeh, M. Tümer, Journal of Hospitality and Tourism Management, 31:265-272(2017).

https://www.sciencedirect.com/science/article/abs/pii/S1447677016301280?via\%3Dih $\underline{\mathrm{ub}}$

2. R.K. Van Ness, K. Melinsky, C.L. Buff, C.F. Seifert, Journal of Managerial Issues, 22(1):10-34(2014). https://www.jstor.org/stable/25822513

3. A.O. Osibanjo, J.O. Akinbode, H.O. Falola, A.O. Oludayo, Journal of Leadership, Accountability and Ethics, 12(1):107-117(2015). http://eprints.covenantuniversity.edu.ng/11367/

4. L. Cichobłaziński, Counterproductive behaviour in organizations: Theoretical background and empirical implications. In : Management and Organization: Concepts, Tools and Applications. C.B., Illés, M. Nowicka-Skowron, E. Horská, Elena, A. Dunay (Eds). UK: Pearson, Harlow. (2017). pp. 49-55. http://real.mtak.hu/50809/

5. L.M. Penney, P.E. Spector, Journal of Organizational Behavior, 26(7):777-796(2005). https://onlinelibrary.wiley.com/doi/abs/10.1002/job.336

6. T.R. Cohen, A.T. Panter, N. Turan, Journal of Business Ethics, 114(1):45-53(2013). https://link.springer.com/article/10.1007\%2Fs10551-012-1326-2

7. B.O. Fagbohungbe, G.A. Akinbode, F. Ayodeji, International Journal of Business and Management,7(5):207(2012). http://www.ccsenet.org/journal/index.php/ijbm/article/view/13117

8. M.L. Gruys, P.R. Sackett, International Journal of Selection and Assessment, 11(1):30-42(2003). https://onlinelibrary.wiley.com/doi/abs/10.1111/1468-2389.00224

9. J. Barling, K.E. Dupré, E.K. Kelloway, Annual Review of Psychology, 60(1):671692(2009). https://www.annualreviews.org/doi/10.1146/annurev.psych.60.110707.163629

10. Z. Bibi, J. Karim, S. Din, Pakistan Journal of Psychological Research, 28(2):317334(2013). http://www.pjprnip.edu.pk/pipr/index.php/pjpr/article/download/309/307

11. L.M. Löschen, P.E. Spector, Journal of Organizational Behavior, 26(7):777796(2005). https://psycnet.apa.org/record/2003-95016-074

12. S. Maleki, M.E. Ansari, S. Mazraeh, H. Arab-Khazaeli, J. Basic. Appl. Sci. Res, 3(4):78-86(2013).

https://pdfs.semanticscholar.org/1eb8/9edf23a0b1bf0c327819483cfbb9a8fdb37b.pdf

13. L.R. Bolton, L.K. Becker, L.K. Barber, Personality and Individual Differences, 49(5):537-541(2010).

https://www.sciencedirect.com/science/article/abs/pii/S0191886910001819?via\%3Dih $\underline{\mathrm{ub}}$ 
14. C. MacKenzie, T.N. Garavan, R. Carbery, Human Resource Development Review, 10(4):346-380(2011). https://journals.sagepub.com/doi/10.1177/1534484311417549

15. T. Furunes, R.J. Mykletun, S. Einarsen, L. Glas $\varnothing$, Nordic Journal of Working Life Studies, 5(2):71(2015). https://tidsskrift.dk/njwls/article/view/26637

16. Š. Babič, CRIS - Bulletin of the Centre for Research and Interdisciplinary Study, 2014(1):61-71(2014). http://archive.sciendo.com/CRIS/cris.2014.2014.issue-1/cris2014-0004/cris-2014-0004.pdf

17. D.S. Kang, J. Stewart, Leadership and Organization Development Journal, 28(6):531551(2007).

https://www.emerald.com/insight/content/doi/10.1108/01437730710780976/full/html.

18. S. Ghoshal, B. Heike, A bias for action: How effective managers harness their willpower, achieve results, and stop wasting time. USA: Harvard Business Press(2004). $\quad$ https://www.amazon.com/Bias-Action-Effective-ManagersWillpower/dp/1591394082

19. A. Dadhich, K.T. Bhal, Vikalpa, 33(4):15-25(2008). https://journals.sagepub.com/doi/10.1177/0256090920080402

20. J.D. Nahrgang, F.P. Morgeson, R. Ilies, Organizational Behavior and Human Decision Processes, 108(2):256-266(2009).

https://www.sciencedirect.com/science/article/abs/pii/S0749597808000939?via\%3Dih $\underline{\mathrm{ub}}$

21. S.J. Wayne, S.A. Green, Human Relations, 46(12):1431-1440(1993). https://journals.sagepub.com/doi/10.1177/001872679304601204

22. D.J. Henderson, S.J. Wayne, L.M. Shore, W.H. Bommer, L.E. Tetrick, Journal of Applied Psychology, 93(6):1208-1219(2008). https://psycnet.apa.org/doiLanding?doi=10.1037\%2Fa0012678

23. T.A. Scandura, G.B. Graen, Journal of Applied Psychology, 69(3):428-436(1984). https://psycnet.apa.org/doiLanding?doi=10.1037\%2F0021-9010.69.3.428

24. P.M., Sias, F.M. Jablin, Human Communication Research, 22(1):5-38(1995). https://academic.oup.com/hcr/article-abstract/22/1/5/4564945?redirectedFrom=fulltext

25. R.C. Liden, S.J. Wayne, R.T. Sparrowe, Journal of Applied Psychology, 85(3):407416(2000). https://psycnet.apa.org/doiLanding?doi=10.1037\%2F0021-9010.85.3.407

26. A. Edmondson, Administrative Science Quarterly, 44(2):350(1999). https://www.jstor.org/stable/2666999?origin=crossref\&seq $=1$

27. A. Van den Broeck, C. Sulea, T. Elst, G. Vander, D. Fischmann, Iliescu, H. De Witte, Career Development International, 19(5):526-547(2014). https://www.emerald.com/insight/content/doi/10.1108/CDI-05-2013-0063/full/html

28. J. Huang, L. Shi, J. Xie, L. Wang, Social Behavior and Personality: An International Journal, 43(8):1273-1286(2015). https://www.ingentaconnect.com/content/sbp/sbp/2015/00000043/00000008/art00005 \%3bjsessionid=3s0pn049ph7cc.x-ic-live-02

29. S. Liu, X. Lin, W. Hu, Social Behavior and Personality: An International Journal, 41(3):357-366(2013). https://www.ingentaconnect.com/content/sbp/sbp/2013/00000041/00000003/art00002

30. P.T. Van den Berg, Psihologia Resurselor Umane, 8(2):42-51(2010). https://www.narcis.nl/publication/RecordID/oai:tilburguniversity.edu:publications\%2 Fe40fdf6a-67d7-4e21-8cec-d11b61b45eb3

31. A.O. De Berker, R.B. Rutledge, C. Mathys, L. Marshall, G.F. Cross, R.J. Dolan, et al., Nature Communications, 7:10996(2016). https://www.nature.com/articles/ncomms10996 
32. D.R. May, R.L. Gilson, L.M. Harter, Journal of Occupational and Organizational Psychology, 77(1):11-37(2004). https://onlinelibrary.wiley.com/doi/abs/10.1348/096317904322915892.

33. W.A. Kahn, Academy of Management Journal, 33(4):692-724(1990). https://journals.aom.org/doi/10.5465/256287.

34. A. Edmondson, R.M. Kramer, K.S. Cook, Trust and Distrust in Organizations: Dilemmas and Approaches, 12:239-272(2004).

https://www.researchgate.net/publication/268328210_Psychological_Safety_Trust_an d Learning in Organizations_A_Group-level_Lens.

35. G.E. Mathisen, S. Einarsen, R. Mykletun, International Journal of Manpower, 33(4):367-382(2012). https://www.emerald.com/insight/content/doi/10.1108/01437721211243741/full/html

36. Y. Gong, S.Y. Cheung, M. Wang, J.C. Huang, Journal of Management, 38(5):16111633(2012). https://journals.sagepub.com/doi/10.1177/0149206310380250

37. P. Kanten, F.E. Ülker, The Macrotheme Review, 2(4):144-160(2013). http://macrotheme.com/yahoo_site admin/assets/docs/12KantenMR24.13191801.pdf

38. O.J. Lasisi, M.Y. Okuneye, O.A. Shodiya, Kuwait Chapter of Arabian Journal of Business and Management Review, 3(9):58-65(2016). https://platform.almanhal.com/Reader/Article/74751

39. D. Pandita, M. Bedarkar, Prabandhan: Indian Journal of Management, 8(7):29(2015). http://www.indianjournalofmanagement.com/index.php/pijom/article/view/72347

40. S. Osborne, M.S. Hammoud, International Journal of Applied Management and Technology, 16(1):50-67(2017). https://scholarworks.waldenu.edu/cgi/viewcontent.cgi?article=1239\&context=ijamt

41. A.K. Samnani, S.D. Salamon, P. Singh, Journal of Business Ethics, 119(2):235244(2014). https://link.springer.com/article/10.1007\%2Fs10551-013-1635-0

42. C.O. Uchenna, Nigerian Journal of Applied Behavioural Sciences, 1:105-114(2013). http://elibrary.aaua.edu.ng/library_files/57b2dec4e525997c29dcfa8f00a7165d.pdf

43. M.J. Martinko, M.J. Gundlach, S.C. Douglas, International Journal of Selection and Assessment, 10(1\&2):36-50(2002).

https://onlinelibrary.wiley.com/doi/abs/10.1111/1468-2389.00192

44. I.I. Uche, O. George, W. Abiola, Acta Universitatis Sapientiae, Economics and Business, 5(1):117-138(2017).

https://content.sciendo.com/view/journals/auseb/5/1/article-p117.xml

45. J. Townsend, J.S. Phillips, T.J. Elkins, Journal of Occupational Health Psychology, 5(4):457-463(2000). $\quad$ https://psycnet.apa.org/doiLanding?doi=10.1037\%2F1076$\underline{8998.5 .4 .457}$

46. P. Dular, M. Markič, Organizacija, 45(2):79-89(2012).http://organizacija.fov.unimb.si/index.php/organizacija/article/view/449

47. L. Chernyak-Hai, A. Tziner, Revista de Psicología Del Trabajo y de Las Organizaciones, 30(1):1-12(2014). https://journals.copmadrid.org/jwop/art/tr2014a1

48. W.J. Kwak, M.H. Lee, J.H. Shim, Advanced Science and Technology Letters, 34(10):38-41(2013). https://www.researchgate.net/publication/301452463 CrossLevel_Effect_of_LMX_Differentiation_on_Subordinate_Distributive_Justice_Percept ion_and_Work_Behaviors_Buffering_Role_of_Team-Oriented_HR_Practices

49. G.B. Graen, M. Uhl-Bien, The Leadership Quarterly, 6(2):219-247(1995). https://www.sciencedirect.com/science/article/pii/1048984395900365?via\%3Dihub.

50. T.M. Probst, L. Jiang, M. Graso, Journal of Safety Research, 56:47-56(2016). https://www.sciencedirect.com/science/article/pii/S0022437515000985?via\%3Dihub 
51. B. Kuvaas, R. Buch, A. Dysvik, T. Haerem, Leadership Quarterly, 23(5):756765(2012).

https://www.sciencedirect.com/science/article/pii/S1048984312000021?via\%3Dihub

52. P.E. Spector, S. Fox, L.M. Penney, K. Bruursema, A. Goh, S. Kessler, Journal of Vocational Behavior, 68(3):446-460(2006).

https://www.sciencedirect.com/science/article/abs/pii/S0001879105001284?via\%3Dih $\underline{\mathrm{ub}}$

53. R.M. Baron, D.A. Kenny, Journal of Personality and Social Psychology, 51(6):11731182(1986). $\underline{3514.51 .6 .1173}$

54. R. Cropanzano, E.L. Anthony, S.R. Daniels, A.V. Hall, Academy of Management Annals, 11(1):479-516(2017). https://journals.aom.org/doi/10.5465/annals.2015.0099

55. L. Furtado, Academy of Management Proceedings, 2018(1):18127(2018). https://doi.org/10.5465/ambpp.2018.18127abstract

56. A. Carmeli, Z. Sheaffer, G. Binyamin, R. Reiter-Palmon, T. Shimoni, Journal of Creative Behavior, 48(2):115-135(2014). https://onlinelibrary.wiley.com/doi/abs/10.1002/jocb.43

57. A. Carmeli, D. Brueller, J.E. Dutton, Systems Research and Behavioral Science, 26(1):81-98(2009). https://onlinelibrary.wiley.com/doi/abs/10.1002/sres.932

58. M.R. Barrick, M.K. Mount, Human Performance, 18(4):359-372(2005). https://www.tandfonline.com/doi/abs/10.1207/s15327043hup1804_3

59. D. Devonish, D. Greenidge, International Journal of Selection and Assessment, 18(1):75-86(2010). $\quad$ https://onlinelibrary.wiley.com/doi/abs/10.1111/j.14682389.2010.00490.x 